\title{
ANALYSIS OF THE FACTORS INFLUENCING THE DECISION ABOUT SEGREGATION BY PEOPLE NOT SEGREGATING THE MUNICIPAL WASTE WITH USING THE AHP METHOD
}

\author{
Ewa Osuch ${ }^{1}$, Andrzej Osuch ${ }^{1}$, Piotr Rybacki ${ }^{1}$, Andrzej Przybylak' ${ }^{1}$, Tatiana Buchwald ${ }^{1}$ \\ ${ }^{1}$ Biosystems Engineering Institute, University of Life Sciences in Poznań, Wojska Polskiego 28 St., 60-637 \\ Poznań, e-mail: ewa.osuch@up.poznan.pl, andrzej.osuch@up.poznan.pl, prybacki@up.poznan.pl, tatiana. \\ buchwald@up.poznan.pl, andrzejp@up.poznan.pl
}

Received: 2016.07.01 Accepted: 2016.08.16 Published: 2016.09 .20

\begin{abstract}
Waste management is one of the most important problems concerning contemporary civilization. The increase of the number of population and consumerism, cause producing different kinds of waste. Along with the economic progress and the technical progress, humanity became the largest producer of waste in nature. Segregation is still the biggest problem of selective collection of waste. The awareness and the knowledge of people in caring about the natural environment is growing. Unfortunately, many of them are not convinced to sort municipal waste. However, in making a decision about segregation, each of them could be influenced by other factors. The aim of this study was to collect detailed criteria which influence the decision about waste segregation among people not segregating the municipal waste. Then the main criteria were grouped and their influence on the global decision was shown. In this paper a method of the Analytical Hierarchization of the Process was used. Research was conducted among 50 randomly chosen respondents from Poland. The results of the research showed that the financial penalties and the possibility of reducing the payment for sorted municipal waste could increase the amount of people who segregate the municipal waste. Increasing the awareness of reducing the natural resources consuming is not as important criterion as two mentioned before.
\end{abstract}

Keywords: waste segregation, municipal waste, determinants of decision-making process, the AHP method

\section{INTRODUCTION}

The environment in which we live at present is encumbered with pollutants coming from the inappropriate waste management. It is important to search for methods of relieving the influence of waste on the environment and aspire to segregate the municipal waste [Jamróz and Generowicz 2012, Kempa 2001]. The population and the consumerism are increasing, causing producing different kinds of waste [Iżykowska-Kujawa 2013, Jamróz and Generowicz 2012, Kuboń 2013]. The households and the public buildings are basic sources of the municipal waste associated with the everyday life of human population
[Bień and Bien 2010]. The increasing amount of the municipal waste from the households and industrial buildings degraded natural environment. Growing costs of the recycling of the municipal waste cause coming into existence of illegal landfill sites [Bieniek et al. 2014], which as a result of physicochemical transformations can directly influence the air pollution [Miaśkiewicz-Peska and Szyłak-Szydłowski 2015, Białowiec et al. 2008] and pollute water and the soil [Wójcik 2010, Szyłak-Szydłowski and Grabińska-Łoniewska 2009]. In the well designed system of the management of the municipal waste, a waste segregation is a basic component. It can be carried out through the system of selective collection from 
places where waste is stored or by the secondary segregation in by a special companies of neutralizing waste [Bień and Bień 2010]. The strategy for the waste disposal in the future should be based on a growth of importance of an action for the waste segregation, and then of different forms of rendering them harmless. Waste segregation should become a universal duty of people [Jamróz and Generowicz]. In 1999 the Council of the European Union issued a directive 1999/31/WE about the waste disposal. According to this document, members of the European Union should take all action being aimed at a curtailment of waste coming into existence. It is regarding also increasing the participation of the recycling of the recyclable waste by the selective collection of waste and implementing systems of the sorting on landfill sites [Czarnocki 2013, Boer and Boer 2007, Kotovicová 2010]. From the moment of the accession of Poland to community of the European Union in 2004, we are obliged to implement relevant acts and other normative acts in the destination of the adaptation to the European Union directives [Bieniak et al. 2014, Kozłowska 2006]. Dealing with waste in our country by the way of the transposition of a directive governed is an act of 14 December 2012 (Dz.U. [Dz] pkt 21, 2013), which came into force on 23 January 2013 [Jakubus and Tatuśko 2015, Czarnocki 2013]. The act implements substantial changes in the system of the waste disposal. A new methodology of dealing with waste was appointed. According to this act, preventing coming into existence of waste is the most important aim [Jakubus and Tatuśko 2015]. Moreover, article 105 informs that waste before putting them on the landfill sites should be subjected to the process of physical, chemical, thermal or biological transforming. It causes that the negative environmental impact is minimalizing. It is the best solution for the health of people and for reducing the amount or volumes of stored waste [Czarnocki 2013]. The problem of the management of waste is widely described in literature [Kuboń 2007; 2008; 2013, Korzeniowski 1999; 2001, Rosik-Dulewska 2003, Żakowska 2003; 2008, Szołtysek 2009]. The law defined rules of proceedings with waste, however, an aspiration to limiting the amount of waste is still most important [Mystowski 2008, Koller 1996]. Acting in the social education should be multidirectional to ac- complish established goals [Pawul and Sobczyk 2011, Dobrowolski 2009, Cichy and Tuszyńska 2006, Niedziałkowski 2002]. Segregating waste in households is still the biggest problem. The implementation and the development of the selective collection are a long term process. It requires new investment in technical and organizational aspects of the waste collecting. An environmental awareness of residents is a crucial element assisting waste disposal [Bień and Bień 2010]. However, how Jakubus and Tatuśko mentioned [2015] wide propagation of information about the need to segregate rubbish causes that the social awareness in this area is sufficient. Meanwhile, so far a $6.8 \%$ of the municipal waste produced per annum was provided with the selective collection of waste [Jamróz and Generowicz 2012]. The waste disposal still constitutes a problem in Poland. Seeking all available and intentional methods for the improvement the indicators of sorted waste is becoming intentional. It is important to look for other arguments, which can contribute to increase the number of people segregating waste. It is possible to distinguish a lot of factors influencing the decision of segregating municipal waste. The financial penalties, increasing the awareness of environmental protection or limiting of waste stored on landfill sites belongs to them. Determining importances of individual determinants is becoming significant in the process of making a decision about fulfilling the public obligation. Analysis of the data causing that in the article selection and hierarchization of the main criteria influencing the decision about segregation by people not segregating the municipal waste was made. In this paper a method of the Analytical Hierarchization of the Process was used. It was used to the identification and putting main criteria in decreasing order according to the impact on the possibility of the decision change.

\section{AIM OF THE RESEARCH, MATERIAL AND METHODS}

The outline of issues presented in the introduction confirm the need of research of the factors influencing the decision about segregation by people not segregating the municipal waste. In the research only persons who are not segregat- 
ing waste at present participated. The aim of the study was to identify the set of main and detailed criteria. Both kinds of the criteria could influence the decision about segregating waste. The main criteria was compared in pairs and put in order according to the decreasing influence on the decision. The importance of the identified criteria (containing the weight of detailed criteria), was appointed using the method of Analytic Hierarchy Process - AHP. This method was invented in 1970 by the American scientist T. L. Saaty [1986] and included mathematical and psychological aspects [Wijnmalen et al. 2009, Doloi 2008, Ayag 2007]. The AHP method gives the possibility to the hierarchization of choosen criteria, even in the case when there is plenty of criteria in the decision-making process. The experts define the detailed and main criteria. The knowledge and the experience of the experts let them define the numerical measure of the importance for analysed criteria [Osuch et al. 2016, Osuch et al. 2015, Rybacki and Durczak 2012]. For fulfilling the purpose of the study an identification of persons not segregating municipal waste and conducting research among them were made. The analysis carried out on 50 people from different regions of Poland. Respondents determined the detailed criteria, which enforced the decision about segregating municipal waste. Next, the detailed criteria were grouped in the main criteria. According to the accepted methodology, the determining of the bank conditions for the number of criteria lets avoid the inconsistency of comparison in pairs. The total number of comparisons should fluctuate within the limits of 5-9. The single criterion cannot be compared with more than $7 \pm 2$ criteria at the same time. In other case it is impossible to distinguish the criteria [Saaty 1986, 1990, 2001]. In the next stage participants allotted the specific number from the pool of 100 points, for each of the main criteria. Appointed evaluations by the respondents are creating the matrix of comparisons in pairs $C_{n n}$, size $n \cdot n$, where $n$ was a number of all the compared main criteria. They were put in order one by one in headlines of lines and columns of the matrix. The rates $\mathrm{a}_{\mathrm{ij}}$ which are written down on the cut of $i$-line with $j$-column were the elements of the matrix, equation 1 :

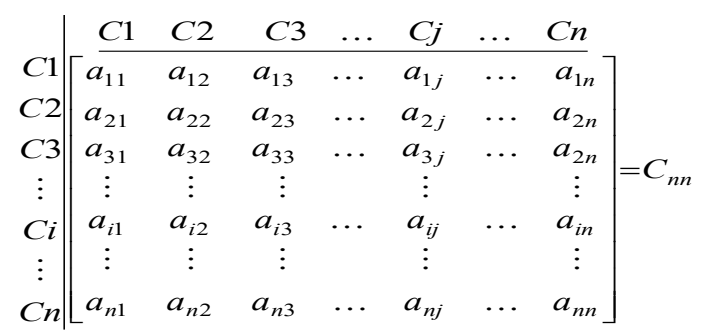

where: $i, j=1,2,3, \ldots, n$.

Every of the matrix should meet the condition 2:

$$
a_{i j}=\frac{1}{a_{j i}},
$$

where: $i, j=1,2,3, \ldots, n$.

The procedure of establishing the ranking of main criteria consists in normalizing columns of the matrix $C_{n n}=\left[a_{i j}\right]$, to the matrix $\overline{C_{n n}}=\left\lfloor\overline{a_{i j}}\right\rfloor$, according to 3 :

\begin{tabular}{|c|c|c|c|c|c|c|c|c|}
\hline & $C 1$ & $C 2$ & $C 3$ & $\ldots$ & $C j$ & $\ldots$ & $C n$ & \\
\hline$C 1 \|$ & $\overline{a_{11}}$ & $\overline{a_{12}}$ & $\overline{a_{13}}$ & $\cdots$ & $\overline{a_{1 j}}$ & $\ldots$ & $\overline{a_{1 n}}$ & \\
\hline$C 2$ & $\overline{a_{21}}$ & $\overline{a_{22}}$ & $\overline{a_{23}}$ & $\ldots$ & $\overline{a_{2 j}}$ & $\ldots$ & $\overline{a_{2 n}}$ & \\
\hline C3 & $\overline{a_{31}}$ & $\overline{a_{32}}$ & $\overline{a_{33}}$ & $\ldots$ & $\overline{a_{3 j}}$ & & $\overline{a_{2 n}}$ & \\
\hline & $\vdots$ & $\vdots$ & $\vdots$ & & $\vdots$ & & $\vdots$ & \\
\hline$C i$ & $\overline{a_{i 1}}$ & $\overline{a_{i 2}}$ & $\overline{a_{i 3}}$ & $\cdots$ & $\overline{a_{i j}}$ & $\ldots$ & $\overline{a_{i n}}$ & \\
\hline$\vdots$ & $\vdots$ & $\vdots$ & $\vdots$ & & $\vdots$ & & $\vdots$ & \\
\hline & $\overline{a_{n 1}}$ & $\overline{a_{n 2}}$ & $\overline{a_{n 3}}$ & $\ldots$ & $\overline{a_{n j}}$ & $\ldots$ & $\overline{a_{n n}}$ & \\
\hline
\end{tabular}

where:

$$
\overline{a_{i j}}=\frac{a_{i j}}{\sum_{i=1}^{n} a_{i j}},
$$

Next the mean of weight of the $\overline{w_{C, i j}}$ criteria are appointed in every of $\overline{C_{n n}}$ matrix, according to equation 5 .

$$
\overline{w_{C i j}}=\frac{\sum_{i=1}^{n} \overline{a_{i j}}}{n},
$$

where: $i, j=1,2,3, \ldots, n$.

As a result every of the main criteria has as many weights $\overline{w_{C i j}}$ as many respondents participated in the research. Therefore, determining the global weight $w C, j$ for the criterion $C i$ is necessary, according to equation 6 :

$$
w_{C i}=\frac{\sum_{j=1}^{n} \overline{w_{C i j}}}{n},
$$

where: $w_{C, j}$ - the global weight of $i$-criterion,

$\overline{w_{C i j}}$ - the detailed weight of $i$-main criterion defined by $j$-participant,

$n-$ the number of participants. 


\section{RESULTS AND DISCUSSION}

Waste is one of the most important environmental problems in Poland and all over the world. 135 million tons of waste are created in Poland annually. Respondents established the identity of the detailed criteria. Next, the criteria were grouped into the hierarchized main criteria (contained rates of the detailed criteria). According to the knowledge and experience of the respondents, the main criteria can have a fundamental influence on the proces of segregation the municipal waste. These criteria (collected in Table 1), contain material and immaterial aspects of decisionmaking processes. Their order of putting in the table 1 was random.

Everyone of the participants in the research evaluate the main criteria of the hierarchization process. The results were presented in Table 2 . Each of respondents allotted the number from the pool of 100 points for each of main criterion. Rate ' 0 ' meant that the factor was not important for the participant. Rate ' 100 ' meant that only one of the criteria was important and completely influenced the decision about segregating waste.

The individual evaluation of main criteria allows their hierarchization (Table 3). Symbol '>' describing different levels in analysed hierarchy of the main criteria. Symbol ' $=$ ' describing the same levels. For the participant $R l$ the most important criterion is $C l$, which is equvalent to $C 7$. Next equivalent criterion are $C 5$ and $C 6, C 4$ and $C 8$. The least important criteria are $C 2$ and $C 3$. They would have the smallest impact for the change of the decision of waste segregation by the R1 participant.

Using the hierarchical system of adopted main criteria (presented in table 3), comparisons were made and the matrix of comparisons in pairs was created. For the analysis of the main criteria evaluation scale was adopted, which was placed in Table 4 .

The matrix of comparisons in pairs for one of the respondents was placed in Table 5.

The matrixes of comparisons in pairs allowed to show the value of the detailed criteria (Table 6). Each of them had as many of detailed criteria as many were respondents in the research. For the respondent $R 1$, the most important criterion was $C 1$ - financial penalties. It has detailed criterion with value 0.56 . For the respondent $R 2$, the most important criteria with value 0.22 , were $C 3$ i $C 4$, which mean increasing the awareness of reducing of consuming of the natural resources and increasing the awareness of saving of the energy.

The equation 6 (from methodology chapter) let to estimate the global value of the main criteria of the entire decision-making process. The criterion with the greatest global weight $(0.23)$ was financial penalties $(C 1)$. The smallest weight (0.09) had criteria $\mathrm{C} 3, \mathrm{C} 4, \mathrm{C} 5, \mathrm{C} 7, \mathrm{C} 8$, i.e.: increasing the awareness of reducing the consumption of the natural resources, increasing the awareness of saving of the energy, increasing the effectiveness of the recycling of the recyclable waste, increasing the awareness of environmental protection and limiting of waste stored on landfill sites.

Table 1. Main criteria of the decision-making process, influencing the decision about segregation by people not segregating the municipal waste.

\begin{tabular}{|c|l|}
\hline Criterion symbol $\mathrm{Ci}$ & \\
\hline C1 & financial penalties \\
\hline C2 & reducing of the payment for sorted municipal waste \\
\hline C3 & increasing the awareness of reducing of consuming of the natural resources \\
\hline C4 & increasing the awareness of saving of the energy \\
\hline C5 & increasing the effectiveness of the recycling of the recyclable waste \\
\hline C6 & reducing prices of products from the recycling \\
\hline C7 & increasing the awareness of environmental protection \\
\hline C8 & limiting of waste stored on landfill sites \\
\hline
\end{tabular}


Table 2. Evaluation of the main criteria

\begin{tabular}{|c|c|c|c|c|c|c|c|c|}
\hline \multirow{2}{*}{ No. } & \multicolumn{8}{|c|}{ Evaluation of the main criteria } \\
\hline & C1 & $C 2$ & C3 & C4 & C5 & C6 & $C 7$ & C8 \\
\hline $\mathrm{R} 1$ & 20,0 & 5,0 & 5,0 & 10,0 & 15,0 & 15,0 & 20,0 & 10,0 \\
\hline $\mathrm{R} 2$ & 2,5 & 50,0 & 10,0 & 5,0 & 20,0 & 5,0 & 5,0 & 2,5 \\
\hline R3 & 70,0 & 20,0 & 0,0 & 0,0 & 0,0 & 0,0 & 10,0 & 0,0 \\
\hline $\mathrm{R} 4$ & 40,0 & 50,0 & 0,0 & 0,0 & 0,0 & 0,0 & 0,0 & 10,0 \\
\hline R5 & 10,0 & 30,0 & 10,0 & 5,0 & 10,0 & 20,0 & 10,0 & 5,0 \\
\hline $\mathrm{R} 6$ & 30,0 & 10,0 & 10,0 & 10,0 & 10,0 & 10,0 & 5,0 & 15,0 \\
\hline $\mathrm{R} 7$ & 30,0 & 10,0 & 10,0 & 10,0 & 10,0 & 10,0 & 10,0 & 10,0 \\
\hline R8 & 5,0 & 5,0 & 5,0 & 3,0 & 2,0 & 30,0 & 20,0 & 30,0 \\
\hline R9 & 0,0 & 0,0 & 16,6 & 16,6 & 16,7 & 16,7 & 16,7 & 16,7 \\
\hline R10 & 40,0 & 30,0 & 2,5 & 2,5 & 15,0 & 2,5 & 5,0 & 2,5 \\
\hline R11 & 0,0 & 0,0 & 50,0 & 30,0 & 20,0 & 0,0 & 0,0 & 0,0 \\
\hline R12 & 40,0 & 20,0 & 0,0 & 0,0 & 20,0 & 0,0 & 20,0 & 0,0 \\
\hline $\mathrm{R} 13$ & 0,0 & 30,0 & 0,0 & 20,0 & 0,0 & 20,0 & 0,0 & 30,0 \\
\hline R14 & 70,0 & 30,0 & 0,0 & 0,0 & 0,0 & 0,0 & 0,0 & 0,0 \\
\hline R15 & 50,0 & 50,0 & 0,0 & 0,0 & 0,0 & 0,0 & 0,0 & 0,0 \\
\hline R16 & 0,0 & 0,0 & 50,0 & 30,0 & 20,0 & 0,0 & 0,0 & 0,0 \\
\hline R17 & 40,0 & 20,0 & 0,0 & 0,0 & 20,0 & 0,0 & 20,0 & 0,0 \\
\hline R18 & 0,0 & 30,0 & 0,0 & 20,0 & 0,0 & 20,0 & 0,0 & 30,0 \\
\hline R19 & 70,0 & 20,0 & 0,0 & 0,0 & 0,0 & 10,0 & 0,0 & 0,0 \\
\hline R20 & 50,0 & 40,0 & 0,0 & 0,0 & 0,0 & 10,0 & 0,0 & 0,0 \\
\hline R21 & 40,0 & 30,0 & 5,0 & 0,0 & 0,0 & 20,0 & 0,0 & 5,0 \\
\hline R22 & 30,0 & 30,0 & 4,0 & 5,0 & 5,0 & 20,0 & 5,0 & 1,0 \\
\hline $\mathrm{R} 23$ & 30,0 & 30,0 & 9,0 & 8,0 & 7,0 & 7,0 & 4,0 & 5,0 \\
\hline R24 & 35,0 & 26,0 & 9,0 & 8,0 & 7,0 & 7,0 & 3,0 & 5,0 \\
\hline R25 & 20,0 & 5,0 & 5,0 & 10,0 & 15,0 & 15,0 & 20,0 & 10,0 \\
\hline R26 & 10,0 & 50,0 & 10,0 & 0,0 & 20,0 & 5,0 & 5,0 & 0,0 \\
\hline R27 & 70,0 & 20,0 & 0,0 & 0,0 & 0,0 & 0,0 & 10,0 & 0,0 \\
\hline R28 & 40,0 & 50,0 & 0,0 & 0,0 & 0,0 & 0,0 & 0,0 & 10,0 \\
\hline R29 & 10,0 & 30,0 & 10,0 & 5,0 & 10,0 & 20,0 & 10,0 & 5,0 \\
\hline R30 & 20,0 & 40,0 & 5,0 & 5,0 & 5,0 & 15,0 & 5,0 & 5,0 \\
\hline R31 & 30,0 & 50,0 & 0,0 & 5,0 & 0,0 & 10,0 & 0,0 & 5,0 \\
\hline R32 & 40,0 & 50,0 & 0,0 & 0,0 & 0,0 & 5,0 & 0,0 & 5,0 \\
\hline R33 & 50,0 & 50,0 & 0,0 & 0,0 & 0,0 & 0,0 & 0,0 & 0,0 \\
\hline R34 & 60,0 & 20,0 & 0,0 & 0,0 & 0,0 & 20,0 & 0,0 & 0,0 \\
\hline R35 & 15,0 & 15,0 & 10,0 & 10,0 & 10,0 & 15,0 & 15,0 & 10,0 \\
\hline R36 & 25,0 & 25,0 & 5,0 & 5,0 & 5,0 & 25,0 & 5,0 & 5,0 \\
\hline R37 & 30,0 & 30,0 & 0,0 & 0,0 & 5,0 & 30,0 & 5,0 & 0,0 \\
\hline R38 & 15,0 & 35,0 & 10,0 & 10,0 & 10,0 & 10,0 & 10,0 & 0,0 \\
\hline R39 & 15,0 & 15,0 & 10,0 & 20,0 & 10,0 & 20,0 & 5,0 & 5,0 \\
\hline R40 & 20,0 & 40,0 & 5,0 & 5,0 & 5,0 & 15,0 & 5,0 & 5,0 \\
\hline R41 & 30,0 & 50,0 & 0,0 & 5,0 & 0,0 & 10,0 & 0,0 & 5,0 \\
\hline R42 & 40,0 & 50,0 & 0,0 & 0,0 & 0,0 & 5,0 & 0,0 & 5,0 \\
\hline R43 & 30,0 & 30,0 & 0,0 & 0,0 & 5,0 & 30,0 & 5,0 & 0,0 \\
\hline R44 & 30,0 & 30,0 & 5,0 & 5,0 & 5,0 & 20,0 & 5,0 & 0,0 \\
\hline R45 & 30,0 & 30,0 & 9,0 & 8,0 & 7,0 & 7,0 & 4,0 & 5,0 \\
\hline R46 & 35,0 & 26,0 & 9,0 & 8,0 & 7,0 & 7,0 & 3,0 & 5,0 \\
\hline R47 & 12,5 & 17,5 & 20,0 & 20,0 & 12,5 & 10,0 & 5,0 & 2,5 \\
\hline R48 & 13,0 & 13,0 & 13,0 & 12,0 & 12,0 & 13,0 & 12,0 & 12,0 \\
\hline R49 & 10,0 & 20,0 & 10,0 & 10,0 & 15,0 & 15,0 & 10,0 & 10,0 \\
\hline R50 & 5,0 & 15,0 & 15,0 & 15,0 & 15,0 & 5,0 & 15,0 & 15,0 \\
\hline
\end{tabular}


Table 3. Hierarchization of the main criteria

\begin{tabular}{|l|l|}
\hline No. & Hierarchization of the main criteria \\
\hline R1 & $C 1=C 7>C 5=C 6>C 4=C 8>C 2=C 3$ \\
\hline R2 & $C 2>C 5>C 3>C 4=C 6=C 7>C 1=C 8$ \\
\hline R3 & $C 1>C 2>C 7>C 3=C 4=C 5=C 6=C 8$ \\
\hline R4 & $C 2>C 1>C 8>C 3=C 4=C 5=C 6=C 7$ \\
\hline R5 & $C 2>C 6>C 1=C 3=C 5=C 7>C 4=C 8$ \\
\hline R6 & $C 1>C 8>C 2=C 3=C 4=C 5=C 6>C 7$ \\
\hline R7 & $C 1>C 2=C 3=C 4=C 5=C 6=C 7=C 8$ \\
\hline R8 & $C 6=C 8>C 7>C 1=C 2=C 3>C 4>C 5$ \\
\hline R9 & $C 5=C 6=C 7=C 8>C 3=C 4>C 1=C 2$ \\
\hline R10 & $C 1>C 2>C 5>C 7>C 3=C 4=C 6=C 8$ \\
\hline R11 & $C 3>C 4>C 5>C 1=C 2=C 6=C 7=C 8$ \\
\hline R12 & $C 1>C 2=C 5=C 7>C 3=C 4=C 6=C 8$ \\
\hline R13 & $C 2=C 8>C 4=C 6>C 1=C 3=C 5=C 7$ \\
\hline R14 & $C 1>C 2>C 3=C 4=C 5=C 6=C 7=C 8$ \\
\hline R15 & $C 1=C 2>C 3=C 4=C 5=C 6=C 7=C 8$ \\
\hline R16 & $C 3>C 4>C 5>C 1=C 2=C 6=C 7=C 8$ \\
\hline R17 & $C 1>C 2=C 5=C 7>C 3=C 4=C 6=C 8$ \\
\hline R18 & $C 2=C 8>C 4=C 6>C 1=C 3=C 5=C 7$ \\
\hline R19 & $C 1>C 2>C 6>C 3=C 4=C 5=C 7=C 8$ \\
\hline R20 & $C 1>C 2>C 6>C 3=C 4=C 5=C 7=C 8$ \\
\hline R21 & $C 1>C 2>C 6>C 8>C 3=C 4=C 5=C 7$ \\
\hline R22 & $C 1=C 2>C 6>C 4=C 5=C 7>C 3>C 8$ \\
\hline R23 & $C 1=C 2>C 3>C 4>C 5=C 6>C 8>C 7$ \\
\hline R24 & $C 1>C 2>C 3>C 4>C 5=C 6>C 8>C 7$ \\
\hline
\end{tabular}

\begin{tabular}{|c|c|}
\hline No. & Hierarchization of the main criteria \\
\hline R25 & $C 1=C 7<C 5=C 6>C 4=C 8>C 2=C 3$ \\
\hline R26 & $C 2>C 5>C 1=C 3>C 6=C 7>C 4=C 8$ \\
\hline $\mathrm{R} 27$ & $C 1>C 7>C 2=C 3=C 4=C 5=C 6=C 8$ \\
\hline R28 & $C 2>C 1>C 8>C 3=C 4=C 5=C 6=C 7$ \\
\hline R29 & $C 2>C 6>C 1=C 3=C 5=C 7>C 4=C 8$ \\
\hline R30 & $C 2>C 1>C 6>C 3=C 4=C 5=C 7=C 8$ \\
\hline R31 & $C 2>C 1>C 6>C 4=C 8>C 3=C 5=C 7$ \\
\hline R32 & $C 2>C 1>C 6=C 8>C 3=C 4=C 5=C 7$ \\
\hline R33 & $C 1=C 2>C 3=C 4=C 5=C 6=C 7=C 8$ \\
\hline R34 & $C 1>C 2=C 6>C 3=C 4=C 5=C 7=C 8$ \\
\hline R35 & $C 1=C 2=C 6=C 7>C 3=C 4=C 5=C 6$ \\
\hline R36 & $C 1=C 2=C 6>C 3=C 4=C 5=C 7=C 8$ \\
\hline R37 & $C 1=C 2=C 6>C 5=C 7>C 3=C 4=C 8$ \\
\hline R38 & $C 2>C 1>C 3=C 4=C 5=C 6=C 7>C 8$ \\
\hline R39 & $C 4=C 6>C 1=C 2>C 3=C 5>C 7=C 8$ \\
\hline $\mathrm{R} 40$ & $C 2>C 1>C 6>C 3=C 4=C 5=C 7=C 8$ \\
\hline R41 & $C 2>C 1>C 6>C 4=C 5>C 3=C 5=C 7$ \\
\hline R42 & $C 2>C 1>C 6=C 8>C 3=C 4=C 5=C 7$ \\
\hline R43 & $C 1=C 2=C 6>C 5=C 7>C 3=C 4=C 8$ \\
\hline R44 & $C 1=C 2>C 6>C 3=C 4=C 5=C 7>C 8$ \\
\hline R45 & $C 1=C 2>C 3>C 4>C 5=C 6>C 8>C 7$ \\
\hline R46 & $C 1>C 2>C 3>C 4>C 5=C 6>C 8>C 7$ \\
\hline R47 & $C 3=C 4>C 2>C 1=C 5>C 6>C 7>C 8$ \\
\hline R48 & $C 1=C 2=C 3=C 6>C 4=C 5=C 7=C 8$ \\
\hline R49 & $C 2>C 5=C 6>C 1=C 3=C 4=C 7=C 8$ \\
\hline R50 & $C 2=C 3=C 4=C 5=C 7=C 8>C 1=C 6$ \\
\hline
\end{tabular}

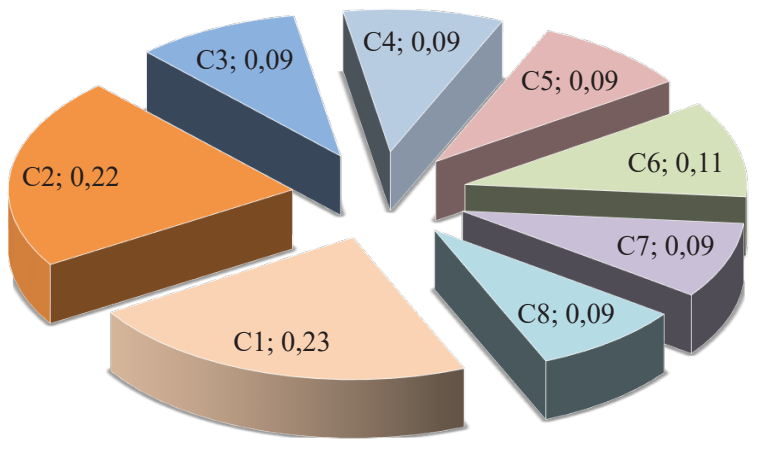

Figure 1. Values of importance of the main criteria of the decision-making process.
Table 4. Adopted evaluation scale of process of comparing in pairs

\begin{tabular}{|c|c|}
\hline Difference in the rating & Rate \\
\hline $0-14$ & 1 \\
\hline $15-28$ & 3 \\
\hline $29-42$ & 5 \\
\hline $43-56$ & 7 \\
\hline $57-70$ & 9 \\
\hline
\end{tabular}

Table 5. Matrix of process of comparing in pairs for one of the research participant

\begin{tabular}{|c|c|c|c|c|c|c|c|c|}
\hline \multicolumn{9}{|c|}{ R1 } \\
\hline Criteria & C1 & C2 & C3 & C4 & C5 & C6 & $C 7$ & $C 8$ \\
\hline C1 & 1,00 & 3,00 & 3,00 & 1,00 & 1,00 & 1,00 & 1,00 & 1,00 \\
\hline C2 & 0,33 & 1,00 & 1,00 & 1,00 & 1,00 & 1,00 & 0,33 & 1,00 \\
\hline C3 & 0,33 & 1,00 & 1,00 & 1,00 & 1,00 & 1,00 & 0,33 & 1,00 \\
\hline C4 & 1,00 & 1,00 & 1,00 & 1,00 & 1,00 & 1,00 & 1,00 & 1,00 \\
\hline C5 & 1,00 & 1,00 & 1,00 & 1,00 & 1,00 & 1,00 & 1,00 & 1,00 \\
\hline C6 & 1,00 & 1,00 & 1,00 & 1,00 & 1,00 & 1,00 & 1,00 & 1,00 \\
\hline$C 7$ & 1,00 & 3,00 & 3,00 & 1,00 & 1,00 & 1,00 & 1,00 & 1,00 \\
\hline C8 & 1,00 & 1,00 & 1,00 & 1,00 & 1,00 & 1,00 & 1,00 & 1,00 \\
\hline$\Sigma$ & 6,67 & 12,00 & 12,00 & 8,00 & 8,00 & 8,00 & 6,67 & 8,00 \\
\hline
\end{tabular}


Table 6. Partial importance of the main criteria.

\begin{tabular}{|c|c|c|c|c|c|c|c|c|}
\hline \multirow{2}{*}{ No. } & \multicolumn{8}{|c|}{ Partial importance of the main criteria } \\
\hline & C1 & $C 2$ & C3 & C4 & C5 & C6 & $C 7$ & C8 \\
\hline $\mathrm{R} 1$ & 0,16 & 0,10 & 0,10 & 0,12 & 0,12 & 0,12 & 0,16 & 0,12 \\
\hline $\mathrm{R} 2$ & 0,06 & 0,46 & 0,08 & 0,06 & 0,15 & 0,06 & 0,06 & 0,06 \\
\hline R3 & 0,53 & 0,13 & 0,05 & 0,05 & 0,05 & 0,05 & 0,06 & 0,05 \\
\hline $\mathrm{R} 4$ & 0,03 & 0,02 & 0,16 & 0,16 & 0,16 & 0,16 & 0,16 & 0,15 \\
\hline R5 & 0,10 & 0,27 & 0,10 & 0,09 & 0,10 & 0,14 & 0,10 & 0,10 \\
\hline $\mathrm{R} 6$ & 0,30 & 0,10 & 0,10 & 0,10 & 0,10 & 0,10 & 0,10 & 0,10 \\
\hline $\mathrm{R} 7$ & 0,30 & 0,10 & 0,10 & 0,10 & 0,10 & 0,10 & 0,10 & 0,10 \\
\hline R8 & 0,07 & 0,07 & 0,07 & 0,07 & 0,07 & 0,21 & 0,21 & 0,21 \\
\hline R9 & 0,05 & 0,05 & 0,15 & 0,15 & 0,15 & 0,15 & 0,15 & 0,15 \\
\hline R10 & 0,32 & 0,23 & 0,07 & 0,07 & 0,08 & 0,07 & 0,07 & 0,07 \\
\hline R11 & 0,05 & 0,05 & 0,41 & 0,21 & 0,14 & 0,05 & 0,05 & 0,05 \\
\hline R12 & 0,34 & 0,15 & 0,05 & 0,05 & 0,15 & 0,05 & 0,15 & 0,05 \\
\hline R13 & 0,05 & 0,22 & 0,05 & 0,17 & 0,05 & 0,17 & 0,05 & 0,22 \\
\hline R14 & 0,48 & 0,22 & 0,05 & 0,05 & 0,06 & 0,05 & 0,05 & 0,04 \\
\hline R15 & 0,35 & 0,35 & 0,05 & 0,05 & 0,05 & 0,05 & 0,05 & 0,05 \\
\hline R16 & 0,05 & 0,05 & 0,41 & 0,21 & 0,14 & 0,05 & 0,05 & 0,05 \\
\hline R17 & 0,34 & 0,15 & 0,05 & 0,07 & 0,15 & 0,05 & 0,15 & 0,05 \\
\hline R18 & 0,05 & 0,22 & 0,05 & 0,17 & 0,05 & 0,17 & 0,05 & 0,22 \\
\hline R19 & 0,53 & 0,13 & 0,05 & 0,05 & 0,05 & 0,06 & 0,05 & 0,05 \\
\hline R20 & 0,37 & 0,28 & 0,06 & 0,06 & 0,06 & 0,06 & 0,06 & 0,06 \\
\hline $\mathrm{R} 21$ & 0,35 & 0,21 & 0,06 & 0,06 & 0,06 & 0,16 & 0,06 & 0,06 \\
\hline R22 & 0,22 & 0,22 & 0,07 & 0,07 & 0,07 & 0,21 & 0,07 & 0,06 \\
\hline R23 & 0,25 & 0,25 & 0,08 & 0,08 & 0,08 & 0,08 & 0,08 & 0,08 \\
\hline $\mathrm{R} 24$ & 0,28 & 0,24 & 0,08 & 0,08 & 0,08 & 0,08 & 0,08 & 0,08 \\
\hline R25 & 0,16 & 0,10 & 0,10 & 0,12 & 0,12 & 0,12 & 0,16 & 0,12 \\
\hline R26 & 0,08 & 0,45 & 0,08 & 0,06 & 0,14 & 0,06 & 0,06 & 0,06 \\
\hline R27 & 0,53 & 0,13 & 0,05 & 0,05 & 0,05 & 0,05 & 0,06 & 0,05 \\
\hline $\mathrm{R} 28$ & 0,29 & 0,36 & 0,06 & 0,06 & 0,06 & 0,06 & 0,06 & 0,06 \\
\hline R29 & 0,10 & 0,28 & 0,10 & 0,09 & 0,10 & 0,15 & 0,10 & 0,09 \\
\hline R30 & 0,18 & 0,36 & 0,07 & 0,07 & 0,07 & 0,09 & 0,07 & 0,07 \\
\hline R31 & 0,22 & 0,42 & 0,06 & 0,06 & 0,06 & 0,06 & 0,06 & 0,06 \\
\hline R32 & 0,29 & 0,37 & 0,06 & 0,06 & 0,06 & 0,06 & 0,06 & 0,06 \\
\hline R33 & 0,35 & 0,35 & 0,05 & 0,05 & 0,05 & 0,05 & 0,05 & 0,05 \\
\hline R34 & 0,49 & 0,14 & 0,05 & 0,05 & 0,05 & 0,14 & 0,05 & 0,05 \\
\hline R35 & 0,13 & 0,13 & 0,13 & 0,13 & 0,13 & 0,13 & 0,13 & 0,13 \\
\hline R36 & 0,21 & 0,21 & 0,07 & 0,07 & 0,07 & 0,21 & 0,07 & 0,07 \\
\hline R37 & 0,24 & 0,24 & 0,05 & 0,05 & 0,07 & 0,24 & 0,07 & 0,05 \\
\hline R38 & 0,10 & 0,32 & 0,10 & 0,10 & 0,10 & 0,10 & 0,10 & 0,09 \\
\hline R39 & 0,12 & 0,12 & 0,12 & 0,16 & 0,12 & 0,16 & 0,10 & 0,10 \\
\hline R40 & 0,18 & 0,36 & 0,07 & 0,07 & 0,07 & 0,09 & 0,07 & 0,07 \\
\hline R41 & 0,22 & 0,42 & 0,06 & 0,06 & 0,06 & 0,06 & 0,06 & 0,06 \\
\hline R42 & 0,29 & 0,37 & 0,06 & 0,06 & 0,06 & 0,06 & 0,06 & 0,06 \\
\hline R43 & 0,24 & 0,24 & 0,05 & 0,05 & 0,07 & 0,24 & 0,07 & 0,05 \\
\hline R44 & 0,22 & 0,24 & 0,07 & 0,07 & 0,07 & 0,19 & 0,07 & 0,06 \\
\hline R45 & 0,25 & 0,25 & 0,08 & 0,08 & 0,08 & 0,08 & 0,08 & 0,08 \\
\hline R46 & 0,28 & 0,24 & 0,08 & 0,08 & 0,08 & 0,08 & 0,08 & 0,08 \\
\hline R47 & 0,12 & 0,14 & 0,16 & 0,16 & 0,12 & 0,12 & 0,10 & 0,08 \\
\hline R48 & 0,13 & 0,13 & 0,13 & 0,13 & 0,13 & 0,13 & 0,13 & 0,13 \\
\hline R49 & 0,13 & 0,13 & 0,13 & 0,13 & 0,13 & 0,13 & 0,13 & 0,13 \\
\hline R50 & 0,13 & 0,13 & 0,13 & 0,13 & 0,13 & 0,13 & 0,13 & 0,13 \\
\hline
\end{tabular}




\section{CONCLUSIONS}

The research and analysis allows to formulate the following conclusions:

1. The financial factors were the most important criteria influencing the decision about segregation by people not segregating the municipal waste. The financial penalties and the possibility of reducing of the payment for sorted municipal waste belongs to these factors. High rates of criteria $\mathrm{Cl}$ and $\mathrm{C} 2$ are proving it.

2. There should be more actions to make the society aware about benefits from the municipal waste segregation. The results of the research showed that many aspects associated with the improvement of environmental protection are not the most important for the respondents.

3. The reduction of prices of products from the recycling may influence the decision about start segregate municipal waste. Therefore these products should be marked with special marks, what will increase the public awareness associated with sorting of waste.

\section{REFERENCES}

1. Ayag Z. 2007. A hybrid approach to machinetool selection through AHP and simulation, International Journal of Production Research, 45/9, 2029-2050.

2. Białowiec A., Bernat K., Wojnowska-Baryła I., Agopsowicz M. 2008. The effect of mechanical pretreatment of municipal solid waste on its potential in gas production, Archives of Environmental Protection, 34, 3, 115-124.

3. Bień B., Bień J. D. 2010. Gromadzenie i selektywna zbiórka odpadów komunalnych w gminach. Inżynieria i Ochrona Środowiska, 13 (3), 173-183.

4. Bieniek J., Najman E., Romański L., Molendowski F., Grabowski J., Kończyło M. 2014. Analiza odpadów komunalnych zbieranych przez wybrane zakłady zagospodarowania odpadów, Inżynieria Rolnicza, 2(150), 15-22.

5. Boer E., Boer W. 2007. Stan i perspektywy. Gospodarka odpadami komunalnymi w Niemczech, Przegląd Komunalny, 5, 24-29.

6. Cichy D., Tuszyńska L. 2006. Edukacja ekologiczna społeczności lokalnych, Problemy ekologii, 10/2, 95-98.

7. Czarnocki S., Paluszkiewicz J. 2013. Struktura i skład odpadów na składowisku w Woli
Suchożebrskiej, Inżynieria Rolnicza, 4(148), 25-30.

8. Dobrowolski D. 2009. Edukacja ekologiczna, Recykling, 2, pp. 29.

9. Doloi H. 2008. Application of AHP in improving con struction productivity from a management perspective, Construction Management and Economics, 26, 839-852.

10. Iżykowska-Kujawa M. 2013. Zagospodarowanie odpadów budowlanych z których korzystamy, Inżynieria Ekologiczna, 33.

11. Jakubus M., Tatuśko N. 2015. Selektywna zbiórka odpadów komunalnych w aspekcie wiedzy i partycypacji społecznej. Inżynieria Ekologiczna, 41, 108-116.

12. Jamróz A., Generowicz A. 2012. Edukacja ekologiczna w gospodarowaniu odpadami na terenie gminy i miasta Skawina. Inżynieria Ekologiczna, 28, 119-130.

13. Kempa E.S. 2001. Strategia gospodarki odpadami na początku XXI wieku, Przegląd Komunalny, 6 (117), 84-86.

14. Köller H. 1996. Kreislaufwirtschafts - und Abfallgesetz. Abfallwirtschaft in Forschung und Praxis. Band 77, Erich Schmidt Verlag, Berlin.

15. Korzeniowski A., Skrzypek M. 1999. Ekologistyka zużytych opakowań, Biblioteka Logistyka.

16. Korzeniowski A., Skrzypek M., Szyszka G. 2001. Opakowania w systemach logistycznych, ILiM, Poznań.

17. Kotovicová J. 2010. Skład i segregacja odpadów komunalnych gospodarstw domowych miasta Blansko, Infrastruktura i Ekologia Terenów Wiejskich, 8/2, 117-126.

18. Kozłowska B. 2006. Wpływ zmian prawa odpadowego na system gospodarki odpadami. Zarządzanie gospodarką odpadami: gospodarowanie odpadami w świetle obowiązującego prawa, Wydawnictwo Futura na zlecenie Polskiego Zrzeszenia Inżynierów i Techników Sanitarnych, Oddział Wielkopolski Poznań.

19. Kuboń M. 2007. Gospodarka opakowaniami jako podstawowy element infrastruktury logistycznej gospodarstw rolniczych, Inżynieria Rolnicza, 8(96), 33-140.

20. Kuboń M. 2008. Koszty gospodarki opakowaniami w gospodarstw o różnym typie produkcji rolniczej, Inżynieria Rolnicza, 4 (102), 431-438.

21. Kuboń M., Kurzawski D. 2013. Gospodarka odpadami opakowaniowymi na przykładzie wybranych gospodarstw Polski południowej, Inżynieria Rolnicza, 2(143), 201-213.

22. Miaśkiewicz-Pęska E., Szydłk-Szydłowski M. 2015. Air pollution in landfill of wastes other than hazardous or inert, Archives of Environmental Pro- 
tection, 41(2), 41-46.

23. Mystowski E. 2008. Rady na odpady, Podlaski Ośrodek Doradztwa Rolniczego w Szepietowie.

24. Niedziałkowski A. 2002. Edukacja czy samokształcenie, Przegląd komunalny, 4, 42-43.

25. Osuch A., Osuch E., Rybacki P., Szulc R., Szwedziak K. 2015. Selekcja i hierarchizacja kryteriów procesu decyzyjnego modernizacji parku maszyn gospodarstw rolnych metodą AHP, Logistyka- nauka, 5, 5188-5194.

26. Osuch E., Osuch A., Podsiadłowski S., Rybacki P., Adamski M., Mioduszewska N. 2016. Analiza czynników wpływających na segregację odpadów przez gospodarstwa domowe $\mathrm{z}$ wykorzystaniem metody AHP. Inżynieria Ekologiczna, 47, 157-162.

27. Pawul M., Sobczyk W. 2011. Edukacja ekologiczna w zakresie gospodarki odpadami jako narzędzie realizacji zrównoważonego rozwoju, Problemy Ekorozwoju, 6 (1), 147-156.

28. Rosik-Dulewska Cz. 2003. Podstawy gospodarki odpadami, PWN, Warszawa.

29. Rybacki P., Durczak K. 2012. Hierarchizacja kryteriów oceny jakości procesów serwisowania maszyn rolniczych metodą porównywania, Inżynieria Rolnicza, 2(136), 299-306.
30. Saaty T.L. 1986. Axiomatic foundation of the analytic hierarchy process, Management Science, 32/7, 841-855.

31. Saaty T. L. 2001. Deriving the AHP 1-9 Scale from First Principles ISAHP, Berne - Switzerland, 397-402.

32. Saaty T.L. 1990. How to make a decision: The analytic hierarchy process, European Journal of Operational Research, 48.1, 9-26.

33. Szołtysek J. 2009. Logistyka zwrotna, Instytut Logistyki i Magazynowania, Poznań.

34. Szyłak-Szydłowski M., Grabińska-Łoniewska A. 2009. Formation of the activated sludge biocenosis during landfi 11 leachate pre-treatment in SBR, Archives of Environmental Protection, 35, 2, 53-66.

35. Wijnmalen D. J. D., Wedley W.C. 2009. Nondiscriminating Criteria in the AHP: Removal and Rank Reversal. Journal of Multi-Criteria Decision Analysis, 15, 143-149.

36. Wójcik W. 2010. Landfi 11 leachate treatment using constructed wetland with short detention time, Archives of Environmental Protection, 36, 3, 51-58.

37. Żakowska H. 2003. Odpady opakowaniowe. Centralny Ośrodek Badawczo-Rozwojowy Opakowań, Warszawa. 